\title{
A review of accounting developments in Africa
}

\author{
Ian Wise \\ Wagner College, New York, USA
}

\section{Keywords}

Accounting, Auditing, Africa, IFRS, Education

\begin{abstract}
Entities in the developing nations of Africa, just like other entities in the developed world need to demonstrate good stewardship in order to attract and retain investment. This means that African countries need a robust accounting infrastructure to deliver reliable and comparable financial information. This paper reviews the current status of accounting in Africa, by looking at the structure of the accounting profession, oversight of accounting entities, currency and monetary control, the status of adoption of International Financial Accounting Standards, the level of accounting research in Africa, and developments in accounting pedagogy at African institutions of higher education. This overview is intended to provide a baseline from which future researchers can develop further investigations into the accounting profession across the continent or a region of Africa.
\end{abstract}

\section{Introduction}

"I often say that when you can measure what you are speaking about, and express it in numbers, you know something about it; but when you cannot measure it, when you cannot express it in numbers, your knowledge is of a meager and unsatisfactory kind; it may be the beginning of knowledge, but you have scarcely, in your thoughts, advanced to the stage of science, whatever the matter may be." Lord Kelvin (Cournot 1847)

Accounting originates in the depths of history. Many Cuneiform Tablets from the Mesopotamian civilization, which were created 5,000 years ago, detail inventory and transfers of property. (The World's oldest Writing 2016). Luca Pacioli codified what we now know as double entry bookkeeping in his Summa de arithmetica, geometria, proportioni et proportionalita (Summary of arithmetic, geometry, proportions and proportionality) in 1494. (Cripps 1994). Modern accounting bodies originated with the founding of the Institute of Chartered Accountants of Scotland in 1854 (Chartered Accountants Worldwide 2020). In 1973 in response to developing global business needs the International Accounting Standards Committee (IASC), was formed. The change to the International Accounting Standards Board (IASB) in 2000 resulted in issuance of International Financial Reporting Standards (IFRS), which have become the de facto international accounting standard worldwide. (IFRS History 2020) IFRS is the required standard in 144 countries and is permitted in many more. (IFRS use around the world 2020)

The developing nations of Africa seek inbound investment, which is critical to developing their economies. Whether that investment comes from for-profit Foreign Direct Investment (FDI), from Governments or from Non-Governmental Agencies (NGO's), the investor requires accountability from the recipient organization. In this case accountability can be quantified through accounting standards which "must be relevant and faithfully represent what it purports to represent. The usefulness of financial information is enhanced if it is comparable, verifiable, timely and understandable" (IFRS Conceptual Framework 2020). Or, as Peter Drucker put it "What gets measured gets managed" (Prusak 2010).

\section{Accounting in Africa}

Globally accounting has developed along two distinct philosophies. In Africa, these philosophies reflect the prior colonial powers.

In Anglophone Africa accounting regulations have been developed by independent bodies, typically called Chartered Accountants. This developed from Common Law Countries where the objective was to provide transparency and information to shareholders who had no direct involvement with the running of the entity.

In Francophone Africa, accounting regulations were defined by legislation. This developed from Code Law countries where the investors such as banks had a more direct involvement with the entity and 
the regulations were designed to define government requirements and tax calculations. Accountants in African Francophone countries are typically called Experts Comptables. (Doupnik 2019)

The Pan African Federation of Accountants, established May 2011, has 54 members in 43 countries and comprises 11,000 professionals. (PAFA). PAFA recognizes the capacity of Professional Accounting Organizations to "drive good financial management practices, accountability, transparency, and good governance across public and private entities." (PAFA 2020)

In addition, PAFA supports the African Professionalization Initiative (API) (PAFA Newsletter 2020).

The API seeks to promote "enhanced accountability, transparency and good governance in the public sector" and result in "public funds being used efficiently and economically to improve the lives of citizens" (African Professionalization Initiative 2020). One of the first organizations of professional accountants in Africa was the Institute of Accountants and Auditors in the South African Republic, which was launched in 1894 with 65 members. (SIACA History 2020). The South African Institute of Chartered Accountants, a successor organization, was established in 1980. The Egyptian Society of Accountants and Auditors (ESAA) was established in 1946 (IFAC Egypt Accountants 2020).The Institute of Chartered Accountants of Nigeria (ICAN) was established in 1965 (IFAC Nigeria 2020)

The Ordre des Experts-Comptables du Royaume de Maroc (OEC-Morocco) was established in 1993. (IFAC Morocco 2020). Over 20 African Professional Accounting Organizations (PAO) are members of the International Federation of Accountants (IFAC), which is the global association of professional accounting organizations. Founded in 1977 it now has 175 members and associates in more than 135 countries and jurisdictions worldwide. Membership of IFAC requires adoption of International Standards and indicates to stakeholders a commitment to best practices and serving the public interest. (IFAC Membership 2020)

\section{Who audits the auditors?}

Accounting bodies have historically been self-regulating, establishing the requirements for qualification, ethical standards and determining the appropriate sanctions for those of their members who transgressed these standards. However, accounting scandals in the early $21^{\text {st }}$ century, which included in the United States (Enron Scandal 2001), in Italy (Parmalat Scandal 2003), and in Ireland (Anglo Irish Bank Scandal 2008) led not only to changes in corporate law but the establishment of independent bodies to review the performance of auditors.

In the United States the Public Company Accounting Oversight Board was created in 2002 (SarbanesOxley Act 2002). In 2006 the International Forum of Independent Audit Regulators (IFIAR) was formed, and it currently has members from 53 jurisdictions worldwide. (IFAIR 2020). Currently the only African countries that are members of IFAIR are Egypt, Botswana, Mauritius and South Africa.

However, in March of 2018, accounting oversight bodies and professional accounting organizations from Botswana, Ethiopia, Lesotho, Malawi, Mauritius, Mozambique, Namibia, Tanzania, South Africa and Zambia joined the Public Accountants and Auditors Board (PAAB) of Zimbabwe in forming the African Forum of Independent Accounting and Auditing Regulators (AFIAAR). The goals are to achieve a common base for Accounting and Auditing standards, and, to work towards attaining IFIAR Standards.

"In the context of the development of our continent, this is a momentous initiative for Africa as it will be one of the keys to increasing investment in our economies, public protection and contributing to the development of the continent." Admire Ndurunduru, Secretary PAAB. (Regulators meet to improve African auditing and accounting standards 2020)

\section{Currency}

The metric used in accounting is the currency of the respective country. Most African countries have their own currency supervised by a Central Bank. The role of a Central Bank in managing Monetary Policy has been defined as comprising the roles of: Inflation Targeting - many Central Banks have established an explicit target inflation rate; Money Supply - adjusting the supply of money through open market operations; Foreign Exchange - determining a desired FX regime and engaging in open market activities; and Macro-prudential Policy - use of bank supervision to minimize systemic risk (IMF Central Banking 2020) 
Central Banks have existed for a long time - the Bank of England since 1694 (Bank of England 2020), Bank of Japan since 1882 (Bank of Japan 2020), Federal Reserve since 1913 (Federal Reserve Act of 1913) and the European Central Bank since 1998 (European Central Bank 2020).

In Africa, examples of Central Banks from some of the largest economies include.

\section{South Africa}

The South African Reserve Bank (SARB) was established in 1920 as a private company. "The primary purpose of the Bank is to achieve and maintain price stability in the interest of balanced and sustainable economic growth in South Africa. Together with other institutions, it also plays a pivotal role in ensuring financial stability." (South African Reserve Bank 2020)

\section{Nigeria}

The Central Bank of Nigeria (CBN) was established in 1958. Its policy is stated as "In order to facilitate the attainment of price stability and to support the economic policy of the Federal Government, there shall be a Committee of the Bank known as the Monetary Policy Committee" (Central Bank of Nigeria 2020)

Egypt

The Central Bank of Egypt (CBE) was established as an autonomous regulatory body in 2003. The President of Egypt appoints the Governor. The main objectives of the CBE include realizing price stability and ensuring the soundness of the banking system, formulating and implementing the monetary, credit \& banking policies, supervising the banking sector, managing the foreign currency international reserves of the country, and regulating the functioning of the foreign exchange market. (Central Bank of Egypt 2020)

\section{Zimbabwe}

Zimbabwe suffered a raging hyperinflation in 2008-09 when prices doubled every 24 hours. The country scrapped its own currency in 2009 and relied on the US Dollar, the South African Rand and other currencies for exchange transactions. In 2016 the government introduced bond notes and coins, but the population showed little faith in them. US Dollar and other foreign currencies were banned in June 2019 and a new Zimbabwe Dollar was introduced in November 2019, but inflation is still estimated to be $300 \%$. (BBC News 2019)

\section{Monetary Unions}

There are two major monetary unions in Africa.

The Central African CFA franc (XAF) is the common currency of Cameroon, Central African Republic, Chad, Equatorial Guinea, Gabon and Republic of the Congo. The Central Bank for the XAF is Bank of Central African States (BEAC) which was established in 1972 and is responsible for issuing currency and guaranteeing its stability, promoting financial stability, promoting the smooth functioning of payment and settlement systems, and holding and managing the official foreign exchange reserves of the Member States. (Bank of Central African States 2020)

The West African CFA franc (XOF) is the common currency of Benin, Burkina Faso, Guinea-Bissau, Ivory Coast, Mali, Niger, Senegal and Togo. The Central Bank for the XOF is Central Bank of West African States (BCEAO). A previous colonial organization was transformed into BCEAO in 1959. Monetary Union was established in 1962 as the West African Monetary Union (WAMU). The bank is responsible for issuing currency, managing monetary policy, organizing and monitoring banking activities and providing assistance for the WAMU member states. (Central Bank of West African States 2020)

The CFA Franc was established in 1945. It was originally pegged to the French Franc and from 1999 the Euro. In December 2019, President Macron announced that the CFA Franc would be replaced in West African countries by the ECO. The ECO will remain pegged to the EURO, but the African countries will no longer have to deposit $50 \%$ of their reserves in French Banks and the French will no longer have a seat on the West African Central Bank. It also opens the possibility of additional states joining the union. Ivorian President Alassane Ouattara welcomed the move as a further step away from the colonial past. (End of CFA Franc 2020) 


\section{International Financial Reporting Standards (IFRS)}

The International Accounting Standards Board (IASB) has promulgated International Financial Reporting Standards since 2001. (King \& Case 2017). Worldwide 144 jurisdictions require IFRS for all or most domestic public entities of which 36 are in Africa. (IFRS use around the world 2020)

\section{Western and Central African Countries}

Companies listed on a stock exchange and other publicly accountable companies in the 17 West and Central African Jurisdictions that are members of the Harmonization of Corporate Law in Africa (OHADA) begin using IFRS Standards in Consolidated Financial Statements January 1, 2019

The jurisdictions that are members of the organization are Benin, Burkina Faso, Cameroon, Central African Republic, Chad, Comoros, Cote d'Ivoire, Democratic Republic of Congo, Equatorial Guinea, Guinea-Bissau, Mali, Niger, Republic of the Congo, Senegal \& Togo. (IFRS African Countries 2020)

The transition to IFRS is justified by a desire for international recognition, development of the private sector and achieving comparability of accounting information. (Randriamiarana 2015)

Difficulties in adopting IFRS include the transition from regional accounting policies such as SYSCOHADA (SYSCOHADA revised 2020). Other issues affecting the adoption of IFRS include the rate of change, education of accountants and cultural differences. (Randriamiarana 2015)

\section{North Africa}

Egypt \& Morocco are members of the International Federation of Accountants (IFAC), which requires members to adopt international Standards.

Egyptian Accounting Standards are based on the 2005 version of IFRS (IFAC Egypt 2020)

Elbayoumi, Awadallah \& Basuony (2019) reviewed critical factors in the development of accounting in Egypt. They characterized Egypt as a Code Law Country exhibiting lack of Investor protection, legal inefficiencies, and weak enforcement mechanisms. Reforms include adoption of international standards and improved quality of accounting and auditing. The dominance of the public sector results in accounting regulations that are not market driven. Increased foreign investment has led to a revival of the accounting and auditing profession in Egypt, however there is no monitoring of accounting and auditing practices.

Morocco has committed to IFRS but as of 2016 it was not legally binding except for banks, which have been using IFRS since 2008. (IFAC Morocco 2020)

\section{Other African countries}

Institute of Chartered Accountants of South Africa (SAICA) made the decision to base its accounting standards on IFRS in 1993.

Kenya adopted IFRS in 1998. (Mwaura \& Nyaboga 2009)

IFRS is required in Botswana, Comoros, Eswantini, Ghana, Lesotho, Nigeria, Namibia, Mauritius, Rwanda, Tanzania, Uganda, Zambia \& Zimbabwe and is permitted in Madagascar. (IFRS by Jurisdiction 2020)

Zaiyol, Andrew \& MemgaUdende (2017) concluded that adoption of IFRS in Nigeria had significant impact on the accountability and quality of financial information.

Using data from 205 companies across 13 African countries Tawiah \& Boolaky (2019) found an average IFRS Compliance score of 73.09\% (Minimum 62.86\%, Maximum 85.61\%). They also determined a positive association between Audit Committee competence and Compliance, a positive association between Chartered Accountants on the Board and Compliance and, that compliance is improving over time but there is less Compliance with the latest standards.

Problems in adopting IFRS in Africa include the fact that IFRS were designed for developed countries in matured capital markets. Countries without stock markets have totally different financial reporting needs to industrialized countries Industrialized countries have converged to IFRS on their own terms, whilst edging less developed countries towards adopting them without any modification. Accounting scholars like Ole-Hope (2006) argue that the decision of an investor to invest in a particular country is actually independent of that country's financial accounting system. There is a degree of non-enforceability of regulations in Africa. There is great diversity in the socio-economic settings on that continent. If African countries should adopt IFRS as given, it is unclear how the benefits of IFRS can be measured. And some 
African countries are much dominated by the public sector; other countries depend largely on the private sector. This makes their informational needs differ from each other (Zori 2012)

Another impediment to full implementation of IFRS is the discrimination some black South Africans experienced even after the end of apartheid. Hammond, Clayton \& Arnold (2012) report that the stories of discrimination experienced by black Chartered Accountants contrast sharply with the official version of history as published in professional journals. Racial discrimination combined with economic factors made things especially difficult for black Chartered Accountants, which reduced the diversity of available qualified accountants in the last quarter of the 20 $0^{\text {th }}$ Century. (Hammond, Clayton \& Arnold 2012)

\section{Accounting Research}

In order to fulfill the ambition to adopt IFRS and drive the development of accounting in Africa and influence international standard setting, Africa requires a robust accounting research infrastructure.

Negash, Lemma \& Samkin (2019) have noted that in Anglophone Sub-Sahara Africa (Anglophone SSA), research output is low. This they attribute to factors specific to the institutions of higher education. They conclude that the factors driving academic accounting research, such as regulation, are weaker in Anglophone SSA.

However, the situation is somewhat different in South Africa. Verhof \& Samkin (2017) have noted the strong influence SAICA, and its predecessors have exerted on South African Accounting Syllabi. While SAICA supports accounting research it is conditional on meeting SAICA's particular view on scholarship. While it is important that professional bodies engage in making curriculum include real world situations this should not exclude other areas of research that can contribute to the advancement of the subject.

\section{Accounting Pedagogy}

In order to effectively adopt, implement and fully develop IFRS in Africa a robust accounting infrastructure is required.

The road to qualification for accountants may be expressed as the three E's, namely Education, Examination and Experience. (AICPA 2020) Typically the professional accounting organization will define these requirements however it is also common for the Education component to be delivered by institutions of higher education.

\section{South Africa}

Coetzee \& Shmulian (2013) have described the effect on Pedagogy in South African Universities resulting from the adoption of IFRS. Universities still have the primary objective of preparing students for professional qualification. The change from "rules based" accounting to "principles based" accounting provided opportunities to change from rote learning of accounting rules. IFRS adoption in South Africa posed some difficulty to accounting education programs in terms of the translation into Afrikaans for purposes of supporting textbooks and study material. However, the adoption of IFRS has provided momentum to accounting education programs in embracing more conceptually based teaching of financial reporting, an approach to pedagogy that is acknowledged as ideally suited to preparing students for their careers in the fluidity of the modern financial reporting environment.

Van Rooyen (2015) identified advances in social media in accounting teaching at University of South Africa (Unisa) a distance learning institution. However, many students do not have access or cannot afford to use the Internet regularly.

Accounting lecturers incorporated a number of social media applications into a second-year module that are accessible via mobile phone. It is evident that this enhances the teaching and learning of accounting.

\section{Nigeria}

Olaoye, Ogandipe \& Dada (2019) have reported a positive correlation between formal education and forensic accounting development in Nigeria. The growth of forensic accounting practices is aided by the quality of formal education. The integration of forensic accounting into the curriculum of the Nigerian education system is significantly related to the rate of development in forensic accounting.

Ofoegbu, Okaro \& Okafor (2018) have been more critical of Nigerian accounting education. They cited low curriculum content, and low motivation. They found poor cooperation between tertiary 
institutions, accountancy practitioners and employers. They found teaching philosophy not in line with modern developments, nepotism in recruitment of lecturers and admission of students and no agreement on accounting education to produce graduates suitable for the labor market

However, on the positive side Okafor \& Egbon (2011) found no significant difference between the academic performance of male and female accounting students in undergraduate accounting courses. The reason why female performance tends to compare favorably with that of males in Nigeria may not be unconnected with the current awareness by women that good education would give them access to job opportunities that will earn them respect among men. If women are to gain recognition in this kind of society, and in a specific discipline hitherto dominated by men, they might have to strive for outstanding performance.

\section{Egypt}

Megid (2014) states that E-learning can offer innovative solutions to problems facing conventional education in Egypt, in particular in accounting courses. It will ease overloaded classes in Egyptian colleges, mitigate the high prices of traditional textbooks, reduce transportation problems and the need for continued education and specialized training. It will improve interaction with the international educational community and enhance the level of national education. Findings show an overall positive student attitude toward and satisfaction with the blended learning course and acceptance for responsibility of their learning, but they need direct support and development for their time management skills. Students prefer the blended learning environment rather than fully online learning, as they perceived that student-instructor as well as student-student interaction and collaboration are important issues in the quality assurance of learning.

\section{Ghana}

The results of a study by Ahinful, Tauringana, Bansah \& Essuman (2019) indicate there is a need for accountants for economic development in Ghana.

To improve academic performance, students should be informed of the opportunities and prospects available to accounting professionals. Academic performance was positively correlated with, Volition the student freely chooses to study accounting, and Expectation - the accounting profession brings greater prestige and respect in society. The accounting profession helps one earn a good remuneration. Studying accounting helps to easily find work. Pursuing accounting makes one more likely to succeed in life. Other factors, which can positively affect the outcomes of accounting education, are, Academic Interest - the desire to study accounting and Learning attitude -time and effort expended in learning accounting. (Ahinful, Tauringana, Bansah \& Essuman 2019)

\section{Conclusion}

The development of accounting in Africa is robust but varies by country. Professional accounting organizations are well developed in most jurisdictions, as are Central Banks. Adoption of International Financial Accounting Standards is in place or plans are established to adopt the standards in most countries.

Difficulties in adopting international standards however are significant and require enhancements to the accounting infrastructure. Institutions of higher education need to further develop accounting research and pedagogy in order to support the transition to international standards. This is also necessary so that African nations can play a role in the future development of international standards that will recognize the particular needs of developing countries. The continued development of accounting in Africa will support the growth in African economies by further enhancing stewardship and reporting by African entities in accordance with international standards.

This review is intended to be an introductory overview of current developments across the continent of Africa and across several related accounting topics. It has been limited to a review of published peer reviewed journals, information posted on the websites of recognized professional organizations and limited other published information.

It is hoped that this overview will provide the background from which future researchers can develop further investigations into specific topics such as the structure of the accounting profession, 
auditor supervision, currency, accounting research or accounting pedagogy across the continent or a region of Africa.

\section{References}

African Professionalization Initiative, (2020), https:// professionalisation.africa Downloaded June 28, 2020

Ahinful, Gabriel Sam; Taiuringana, Venancio; Bansah, Ernest Amoaful \& Essuman, Dominic, (2019), “Determinants of academic performance of accounting students in Ghanaian secondary and tertiary education institutions" Accounting Education Dec 2019 Vol 28 Issue 6 p553-581

AICPA, (2020), https://www.aicpa.org/becomeacpa/faqs.html downloaded July 10, 2020

Anglo Irish Bank Scandal, (2008), https:/ / www.ft.com/content/c37841b8-dd76-11e2-a756-00144feab7de Downloaded June 28, 2020

Annelien van Rooyen (2015) “Distance Education Accounting Students' Perceptions of Social Media Integration" Procedia - Social and Behavioral Sciences vol 17620 February 2015 P 444-450

Bank of Central African States, (2020), https://www.devex.com/organizations/banque-des-etats-de-l-afriquecentrale-beac-52137 Downloaded June 28, 2020

Bank of England, (2020), https:/ / www.bankofengland.co.uk/about/history Downloaded June 28, 2020

Bank of Japan, (2020), https:/ / www.boj.or.jp/en/about/outline/history/index.htm/

Downloaded June 28, 2020

BBC News, (2019), Zimbabwe Inflation https://www.bbc.com/news/world-africa-50374402 Downloaded June 28, 2020

Central Bank of Egypt, (2020), https://www.cbe.org.eg/en/AboutCBE/Pages/Overview.aspx Downloaded June 28, 2020

Central Bank of Nigeria, (2020), https://www.cbn.gov.ng/\#_Downloaded June 28, 2020

Central Bank of West African States, (2020), https://www.bceao.int/en/content/missions-bceao Downloaded June 28,2020

Chartered Accountants Worldwide, Institute of Chartered Accountants of Scotland, (2020),

https://charteredaccountantsworldwide.com/the-institute-of-chartered-accountants-of-scotland-icas/ downloaded June 7, 2020

Chinwuba Ambrose Okafor \& Osamuyimen Egbon (2011) “Academic Performance of Male versus Female Accounting Undergraduate Students: Evidence from Nigeria" Higher Education Studies Vol. 1, No. 1; June 2011

Coetzee, Stephen A, and Schmulian, Astrid (2013) The Effect of IFRS Adoption on Financial Reporting Pedagogy in South Africa American Accounting Association ISSUES IN ACCOUNTING EDUCATION Vol. 28, No. 2 2013 pp. 243-251

Cournot, (1847) De l'origine et des limites de la correspondance entre l'algèbre et la géométrie, Antoine-Augustin Paris, L. Hachette, 1847, 375.

Cripps, Jeremy, (1994),Particularis de Computis et Scriptuis, Fra Luca Pacioli, 1494, A contemporary interpretation, Jeremy Cripps, Pacioli Society, Seattle 1994. http://jeremycripps.com/docs/Summa.pdf downloaded June 7, 2020

Elbayoumi, Ahmed F; Awadallah, Emad A; Basuony, Mohamed A K, (2019) “Development of Accounting and Auditing in Egypt: Origin, Growth, Practice and Influential Factors" The Journal of Developing Areas, Nashville Vol 53, Iss. 2 (Spring 2019) 205-220

End of CFA Franc, (2019), https://africatimes.com/2019/12/22/ouattara-macron-announce-the-end-of-the-cfafranc/ Downloaded June 28, 2020

Enron Scandal, (2001), https://www.investopedia.com/updates/enron-scandal-summary/ Downloaded June 28, 2020

European Central Bank, (2020), https://europa.eu/european-union/about-eu/institutions-bodies/european-centralbank_en Downloaded June 28, 2020

Federal reserve Act 1913, (1913) https://www.investopedia.com/terms/f/1913-federal-reserve-act.asp Downloaded June 28, 2020

Hammond T, Clayton, Bruce M \& Arnold, Patricia J (2012) “An "unofficial” history of race relations in South African accounting industry, 1968-2000: Perspectives of South Africa's first Black Chartered Accountants" Critical Perspectives on Accounting Vol 23 Issues 4-5 June 2012 p 322-350

IFAC Egypt Accountants, (2020),

https://www.ifac.org/about-ifac/membership/members/egyptian-society-accountants-auditors downloaded June 28,2020

IFAC Egypt, (2020), https:/ /www.ifac.org/about-ifac/membership/country/egypt Downloaded July 10, 2020

IFAC Membership (2020) https:/ / www.ifac.org/who-we-are/membership Downloaded June 28, 2020

IFAC Morocco, (2020), https://www.ifac.org/about-ifac/membership/country/morocco Downloaded June 28, 2020 
IFAC Nigeria, (2020) https://www.ifac.org/about-ifac/membership/members/institute-chartered-accountantsnigeria Downloaded June 28, 2020

IFAC Our purpose, (2020) https://www.ifac.org/who-we-are/our-purpose Downloaded June 28, 2020

IFAIR, (2020) www.ifiar.org Downloaded June 28, 2020

IFRS African Countries, (2020), https://www.ifrs.org/news-and-events/2018/01/ifrs-foundation-updatesjurisdiction-profiles-to-reflect-decision-by-17-african-countries/ Downloaded June 28, 2020

IFRS by Jurisdiction, (2020), https://www.ifrs.org/use-around-the-world/use-of-ifrs-standards-by-jurisdiction/ downloaded July 10, 2020

IFRS Conceptual Framework, (2020) http://eifrs.ifrs.org/eifrs/bnstandards/en/framework.pdf downloaded June 7, 2020

IFRS History, (2020), https://www.ifrs.org/about-us/who-we-are/\#history downloaded June 7, 2020

IFRS use around the world, (2020) https://www.ifrs.org/use-around-the-world/use-of-ifrs-standards-byjurisdiction/\#analysis Downloaded June 28, 2020

IMF Central Banking, (2020) https://www.imf.org/external/np/exr/facts/pdf/mpcb.pdf

Downnloaded June 28, 2020

International Accounting, Doupnik, Finn, Gotti \& Perera, 5th Edition, 2019 McGraw Hill

King, Darwin L, Case, Carl J, (2017) A Concise History of Professional Accounting Associations, Journal of Business and Accounting Vol 10, No 1; Fall 2017

Minga Negash, Tesfaye T Lemma \& Grant Samkin, (2019) Factors impacting accounting research output in developing countries: An exploratory study, The British Accounting Review, Volume 51, Issue 2 February 2019, p170-192

Muroki F. Mwaura \& Andrew B. Nyaboga, (2009), International Financial Accounting Standards and the Continent of Africa

International Business \& Economics Research Journal - March 2009 Volume 8, Number 3

Nevine Sobhy Abdel Megeid, (2014) "E-LEARNING VERSUS BLENDED LEARNING IN ACCOUNTING COURSES" The Quarterly Review of Distance Education, Volume 15(2), 2014, pp. 35-55

Ofoegbu, Grace N, Okaro, Sunday C \& Okafor, Gloria O, (2018) “Suitability, challenges and way forward for university accounting education in Africa" The International Journal of Management Education, Vol 16, Issue 3, November 2018 p 394-404

Olaoye, Clement Olatunji; Ayobolawole Adewale Ogundipe; Raphael Adekola Dada (2019) "Formal Education and Forensic Accounting Development in Nigeria" Acta Universitatis Danubius. Oeconomica; Galati Vol 15 Iss 2 (2019)

Ole-Hope, Kristian, Jin, Justin Y., Kang, Tony (2006): Empirical Evidence on Jurisdictions That Adopt IFRS. In: Journal of International Accounting Research, 5 (2): 1-20.

PAFA, (2020) https:/ / pafa.org.za downloaded June 28, 2020

PAFA Newsletter, (2020),

https://pafa.org.za/sites/default/files/2020-

06/En_PAFA\%20NEWSLETTER\%20\%20JUNE\%202020\%20EDITION.pdf downloaded June 28, 2020

Parmalat Scandal, (2003), CFA Institute https://www.econcrises.org/2016/11/29/parmalat/ Downloaded June 28, 2020

Prusak, Larry, (2010), “What can't be measured” Harvard Business Review, October 7, 2010,

https://hbr.org/2010/10/what-cant-be-measured downloaded May 18, 2020.

Randriamiarana, Joëlle, (2015), The Role of Accounting in Economic Development: Case of IFRS Development in Western Africa ,Recherches en Sciences de Gestion 2015 Issue 110 p 61-85 25p

Regulators meet to improve African auditing and accounting standards, (2020),

https://www.publicfinancefocus.org/news/2018/03/regulators-meet-improve-african-auditing-and-accountingstandards Downloaded June 28, 2020

SAICA History, (2020),

https://www.saica.co.za/DesktopModules/EngagePublish/printerfriendly.aspx?itemId=618\&PortalId=0\&TabId=70 Downloaded June 28, 2020

Sarbanes-Oxley Act of 2002, (2002), https://www.investopedia.com/terms/s/sarbanesoxleyact.asp Downloaded June 28, 2002

South African Reserve Bank, (2020) https://www.resbank.co.za/Pages/default.aspx Downloaded June 28, 2020

SYSCOHADA revised, BDO, (2020), https://www.bdo-fwa.com/en-gb/insights/featured-insights/syscohadarevised Downloaded July 10, 2020

Tawiah, Vincent and Boolaky, Pran (2019) Determinants of IFRS compliance in Africa: analysis of stakeholder attributes. International Journal of Accounting \& Information Management, 27 (4). pp. 573-599. ISSN 1834-7649 
“The World's Oldest Writing,", (2016) Archeology May/June 2016 https://www.archaeology.org/issues/2131605/features/4326-cuneiform-the-world-s-oldest-writing downloaded May 18, 2020.

Verhof G \& Samkin G (2017) “The Accounting Profession and Education: The Development of Disengaged Scholarly Activity in Accounting in South Africa" Accounting, Auditing and Accountability Journal Vol 30 No 6 p 1370 1398

Zaiyol,Dr. Patrick I, EgwuAchor, Andrew, MemgaUdende, Benjaminn (2017), Impact of IFRS Adoption on Accountability of Nigerian Organisations IOSR Journal of Economics and Finance (IOSR-JEF) e-ISSN: 2321-5933, p-ISSN: 2321-5925.Volume 8, Issue 1 Ver. I (Jan-Feb. 2017), PP 60-72.

Zori, Solomon, (2012) The State of IFRS in Africa: Is IFRS in Disarray? in Governance across borders transnational fields and transversal themes. Edited by Leonhard Dobusch, Philip Mader and Sigrid Quack. 2012/ 01/11 